\section{Экологические аспекты состояния лесов в санитарно-защитных зонах алюминиевых заводов}

\author{
Е. М. Рунова ${ }^{1}$ \\ С. А. Чжан \\ Братский государственный технический \\ университет
}

\begin{abstract}
АННОТАЦИЯ
В статье приводятся результаты экспериментальных исследований по влиянию промышленных выбросов алюминиевого производства на лесные экосистемы в пределах санитарно-защитной зоны, проводившихся с целью изучения влияния фторидов на таксационные показатели древостоев, их жизнеспособность, особенности накопления токсикантов в тканях растений.
\end{abstract}

Ключевые слова: древостой, жизнеспособность, фториды, санитарно-защитная зона, экология.

\section{SUMMARY}

The article presents the results of the experimental investigation of the aluminium industrial emissions influence on the forest ecological systems within the sanitaryprotection zone. The investigation was carried out to study the influence of fluorides on the inventory index of stands, their viability, peculiarities of toxicant accumulation in the trees tissues.

Keywords: wood, viability, fluoric, sanitary - protective zone, ecology.

\section{ПОСТАНОВКА ПРОБЛЕМЫ}

Алюминий, наиболее распространенный металл, представлен в земной коре в основном алюмосиликатами и бокситами. При производстве алюминия наблюдаются значительные потери фтора, которые и приводят к негативным экологическим последствиям. В настоящее время признано, что по влиянию на растения соединения фтора являются одними из самых токсичных. Воздействие фторидов на растения проявляется в повреждении листвы, а также в виде хлороза листвы (потери хлорофилла, некроз тканей и деформация роста листа).

Анализ состояния загрязнения районов расположения алюминиевых заводов и воздействия вредных компонентов на биосферу указывает на необходимость совершенствования как процесса электролиза алюминия, так и систем очистки отходящих газов от наиболее опасных компонентов, а также преобразования зеленых насаждений санитарно-защитных зон в устойчивые и долговечные экосистемы в условиях повышенного антропогенного загрязнения.

\footnotetext{
${ }^{1}$ Авторы - соответственно профессор и доцент кафедры технологии и оборудования лесопромымленных производств
}

(C) Е. М. Рунова, С. А. Чжан, 2003
Цель исследований заключалась в определении состояния древесной растительности в санитарнозащитной зоне алюминиевых заводов (на примере крупнейшего Братского алюминиевого завода), в изучении динамики деградации типичных лесных ландшафтов светлохвойной тайги в разреженные и распадающиеся под воздействием антропогенного загрязнения растительные ценозы.

В литературе наиболее изученными являются вопросы определения количества выбросов при различных технологиях алюминиевого производства, влияния фторидов и других сопутствующих элементов на растительность в лабораторных условиях, а также основные требования к функциям санитарнозащитных зон. Однако слабоизученным является вопрос о длительном влиянии загрязнения алюминиевых заводов на лесные экосистемы в неблагоприятных условиях резко-континентального климата Восточной Сибири и организации восстановления экологического равновесия в санитарных зонах.

В связи с этим необходимы детальное исследование влияния длительного воздействия твердых и газообразных фторидов на растительность санитарнозащитных зон, а также теоретическое обоснование выбора ассортимента древесных и кустарниковых растений, рекомендуемых для посадки в санитарных зонах, организации режима ведения хозяйства в них.

\section{ОБЪЕКТЫ ИССЛЕДОВАНИЯ}

Объектом исследований являются санитарнозащитная зона БрАЗа и прилегающие к ней леса.

\section{МЕТОДИКА ИССЛЕДОВАНИЯ}

Основным методом сбора данных о состоянии лесов является полевое обследование насаждений на пробных площадях.

Пробные площади закладывались как можно ближе к одному из постов наблюдения за загрязнением возду$\mathrm{xa,} \mathrm{чтобы} \mathrm{постоянно} \mathrm{иметь} \mathrm{данные} \mathrm{о} \mathrm{наличии} \mathrm{и} \mathrm{кон-}$ центрации загрязняющих веществ в атмосфере.

Пробные площади закладывались по стандартной методике (ОСТ 56-69-83 Пробные площади лесоустроительные) [1] и по методикам, подробно описанным в литературе $[2,3]$.

Производилось лесоводственно-геоботаническое описание каждой пробной площади, с указанием особенностей древостоя, подроста, подлеска, напочвенного покрова и рельефа. Оценивалось санитарное состояние насаждений, кроны деревьев (характер охвоения, продолжительность жизни хвои, размеры, цвет и величина некроза на листьях, наличие сухих ветвей и суховершинностей).

Затем проводился сплошной перечет по ступеням толщины. Замерялась высота каждого дерева. Данные перечета деревьев обрабатывались статистическими методами с вычислением средних значений. 
Общее состояние деревьев на постоянных пробных площадях оценивалось в баллах по методике [4]: I здоровые деревья; II - ослабленные; III - сильно ослабленные; IY - усыхающие; Y - погибшие.

Для оценки степени повреждения древесной растительности применялась следующая шкала классов дефолиации: 0 - полное охвоение: продолжительность жизни хвои не менее 3 лет (по осенней оценке), побеги и хвоя нормально развиты; 1 - слабая дефолиация (до $25 \%$ ): возраст хвои -2 года, побеги и хвоя хорошо развиты; 2 - сильная дефолиация (до $50 \%$ ): однолетняя хвоя сохранена, годичный прирост побегов часто снижен, встречаются отдельные сухие ветви в кроне; 3 - очень сильная дефолиация: однолетняя хвоя сохранена, а хвоя старших возрастов лишь в небольшом количестве, побеги и хвоя укороченные; 4 - дефолиация достигает 100 \%: хвоя текущего года сохранена лишь частично, охвоение хвоей старшего возраста отсутствует или она очень укороченная; крона сильно усохшая.

Средний балл состояния и класс дефолиации деревьев на пробных площадях рассчитываются как средневзвешенные величины. На пробных площадях производились оценка и описание состояния деревьев.

На пробных площадях были заложены по 20 учетных площадок размером 2х2 м для учета подроста. В пределах каждой площадки учитывался весь подрост с обязательным указанием породы, возраста и высоты, а также указывались замеченные повреждения. Учет естественного возобновления проводился с использованием методов лесной таксации [2]. Оценка проводилась по шкале ВНИИЛМ [2]. Результаты изучения обобщались в виде таблиц, графиков, показывающих влияние промвыбросов на состояние древостоев.

На пробных площадях для определения накопления фтора в растительности брались пробы весной после полного распускания листьев (май - июнь) и осенью (октябрь) перед опаданием с одного и того же дерева. Метод определения накопления фтора основан на измерении ЭДС ионоселективного электрода в зависимости от активности ионов фтора в растворах.

Отбор листьев производился по 5 маршрутам на расстоянии от БрАЗа 1 км, 2 км, 4 км, 6 км, 8 км, т.е. в пределах санитарно-защитной зоны. Пять маршрутов обеспечивали более высокую точность результатов исследований. Рассматривались листья следующих пород: береза повислая (Betula pendula), ольха кустарниковая (Alnus fruticosa), ива козья (Salix caprea), осина (Populus tremula) и хвоя лиственницы (Larix sibirica), поскольку она ежегодно сбрасывает хвою, в результате чего можно проследить ежегодную динамику накопления фторидов. Исследования накопления фтора проводились в течение нескольких лет, начиная с 1997 и по 2002 г., при этом параллельно определялась концентрация фтористого водорода в воде и в снежном покрове по тем же маршрутам и на том же расстоянии от алюминиевого завода.
Определение содержания фтора в растительности проводилось с помощью ионоселективного электрода в зависимости от активности ионов фтора в раствоpax.

Листья тщательно отмывали дистиллированной водой, высушивали при температуре $105-110^{\circ} \mathrm{C}$, тщательно измельчали в агатовой ступке. Навеску растительности $(0,5000-1,000$ г) смешивали с десятикратным количеством калий-натрий карбоната и сплавляли в платиновых тиглях в муфельной печи при температуре $500-600^{\circ} \mathrm{C}$ в течение 3 часов. Сплав выщелачивали 30-50 мл дистиллированной воды, переводили в стакан, осторожно нейтрализовали $20 \%$-ной соляной кислотой (по фенолфталеину), переводили в мерную колбу емкостью 100 мл, отбирали 10 мл, добавляли 10 мл буферного раствора «БРОЙС» и замеряли ЭДС на РН-метре.

Содержание фтора в растительности определяется по формуле:

$$
\begin{aligned}
& A=\frac{a \cdot 100 \cdot 100}{10 \cdot s}, \% \text {, } \\
& B=\frac{a \cdot 1000 \cdot 100}{10 \cdot B}, \text { ма/ке, }
\end{aligned}
$$

где $a-$ содержание фтора по графику, г (I), мг (II), в - навеска, г.

Определение уровня загрязнения почвы фторидами проводилось колориметрическим и потенциометрическим методами. Исследования микробиологической активности проведены на почвенных образцах, взятых на территории санитарно-защитной зоны, а также за ее пределами. Интегральными показателями биологической активности почв являются следующие: интенсивность дыхания почв, азотфиксация. Дыхание и азотфиксацию определяли на одних и тех же образцах, в пенициллиновых флаконах в 2,5 г сухой почвы газохроматографическими методами. Для точности эксперимент повторяли 4 раза. Дыхание выражалось в миллилитрах на 1 кг почвы в час. Азотфиксацию оценивали по редукции ацетилена в этиле и определяли в нем $\mathrm{C}_{2} \mathrm{H}_{4}$ на 1 кг почвы в час или мкг $\mathrm{N}_{2}$ на 1 кг почвы в час $\left(1 \mathrm{Hм} \mathrm{C}_{2} \mathrm{H}_{4}=\right.$ 10 мкг $\mathrm{N}_{2}$ ).

Азотфиксацию определяли с внесением глюкозы (2 \% от веса почвы). Азотфиксацию почвенных образцов оценивали по редукции ацетилена в этилен и определяли в нем $\mathrm{C}_{2} \mathrm{H}_{4} /$ кг почвы в час или мкг $\mathrm{N}_{2} /$ кг почвы в час:

I нM $\mathrm{C}_{2} \mathrm{H}_{4}=10$ мкг $\mathrm{N}_{2}$.

Для пересчета условных единиц (А у.е) в $\mathrm{HM} \mathrm{C}_{2} \mathrm{H}_{4}$ пользуются следующей формулой:

Хннм ${ }_{2}^{2} \mathrm{H}_{4}=\frac{\text { Ау.е. } \cdot 0,1 \% \cdot 12,5 \text { мл } \cdot 10^{9} \cdot 400 \kappa г}{100 \% \cdot 23600 y . е \cdot 22400 \text { мл } \cdot \text { Тчасов }}$ 
Калибровка прибора по этилену для определения азотфиксации $0,1 \% \mathrm{C}_{2} \mathrm{H}_{4}=23600$ у.е. Для пересчета условных единиц в мл $\mathrm{CO}_{2}$ пользуются следующими формулами:

$1 \% \mathrm{CO}_{2}-24$ у.е.; $\mathrm{B}=-\mathrm{A} / 24-\mathrm{X}$ мл;

В \% $\mathrm{CO}_{2}-$ А у.е; $100 \%-12,5$ мл;

$$
\text { Хммл } C_{2}=\frac{\text { Ау.е. } \cdot 12,5 м л \cdot 400 \kappa г}{24 \cdot 100 \% \cdot \text { Тчасов }} .
$$

Экспериментальные данные обработаны статистически. Для оценки достоверности наблюдений применялся критерий Стьюдента.

\section{РЕЗУЛЬТАТЫ ИССЛЕДОВАНИЙ}

Для оценки состояния древесной растительности в санитарно-защитной зоне и за ее пределами были заложены пробные площади, на которых согласно общепринятым методикам произведен учет деревьев. Измерялись следующие таксационные показатели: высота, диаметр, возраст деревьев, возраст и длина хвои, ее состояние, а также устанавливались класс дефолиации и балл категории состояния согласно шкале визуальной оценки степени повреждения хвойных деревьев промышленными выбросами. Были заложены 4 пробные площади, 3 из которых на территории санитарно-защитной зоны и 1 - за ее пределами. Пробные площади закладывались в радиусе 2 км от предприятия, 3 км, 8 км и 18 км.

Общее состояние древесной растительности на пробных площадях характеризуется крайней степенью угнетения, что прослеживается по соотношению среднего диаметра и средней высоты, наличию многовершинности, суховершинности, значительному проценту повреждения хвои и малой продолжительности жизни хвои. На рисунке 1 представлена зависимость класса дефолиации от расстояния от источника загрязнения.

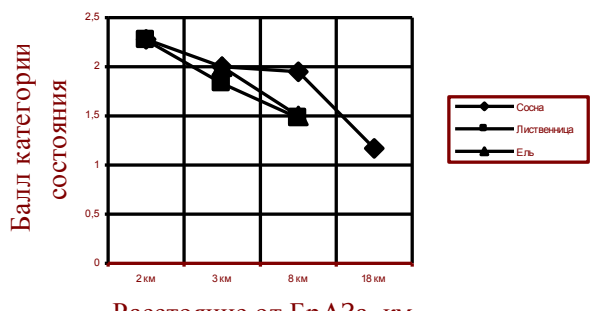

Расстояние от БрАЗа, км

Рис. 1. Зависимость класса дефолиации от расстояния от источника загрязнения: $\diamond$ - сосна, $\square-$ лиственница, $\Delta-$ ель.

Из рисунка видно, что степень дефолиации деревьев с увеличением расстояния уменьшается от 1,2 до 2,3 .

На рис. 2, 3 показано накопление общего фтора в листьях и хвое в динамике. Из рисунков видно, что содержание фтора в листве резко возрастает к концу вегетационного периода - конец сентября - конец октября (примерно в 1,7 - 3,0 раза) по сравнению с началом вегетационного периода.

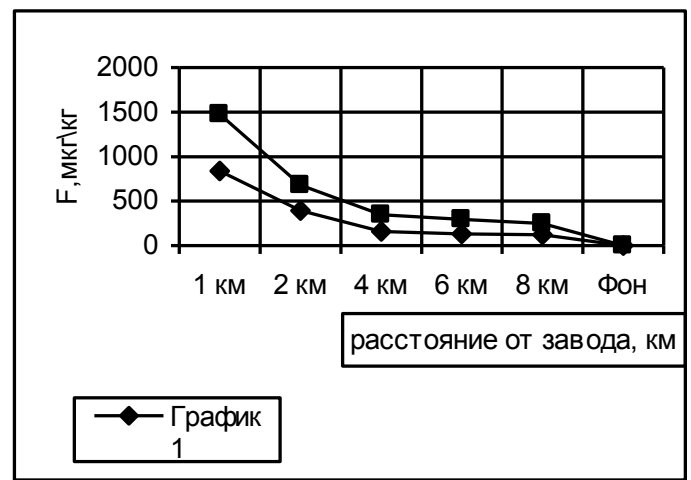

Рис. 2. Накопление общего фтора в листве ( мкг/кг) за июнь - октябрь 2001 г.: $\diamond$ - содержание фтора в июне, $\square$ - содержание фтора в октябре

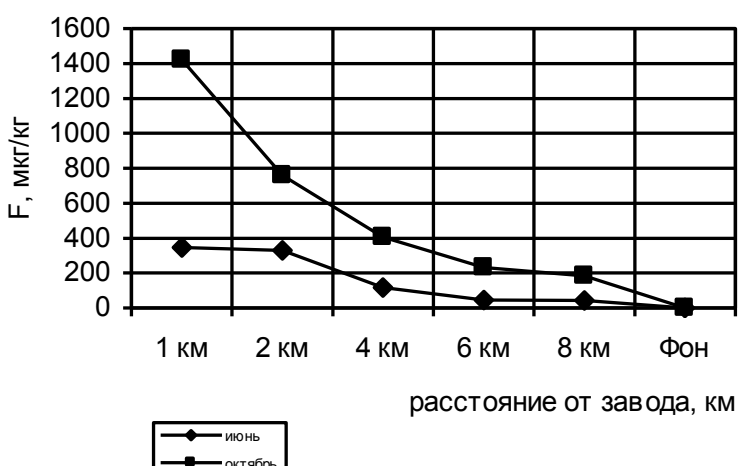

Рис. 3. Накопление общего фтора в листве ( мкг/кг) за июнь - октябрь 2002 г.: $\diamond$ - содержание фтора в июне, $\square-$ содержание фтора в октябре

На рис. 2, 3 показана динамика накопления фторидов за июнь - октябрь 2001-2002 г. В начале июня максимальная концентрация фтора в листве не превышает 800 мкг/кг (на расстоянии 1 км от БрАЗа), на расстоянии $2-8$ км содержание фторидов колеблется в пределах 150 - 250 мкг/кг, что свидетельствует о наиболее высокой степени загрязнения непосредственно в районе завода (в радиусе $1-2$ км).

В октябре концентрация фторидов резко увеличивается, максимальное значение на расстоянии 1 км от завода составляет уже 1600 мкг/кг. В зоне от 4 до 8 км содержание фторидов не превышает 500 мкг/кг. В 2001, 2002 гг. в качестве контроля исследовалась листва в фоновой зоне на расстоянии 60 км от источника загрязнения. Данные по фоновой зоне свидетельствуют о крайне низком уровне фторидов как в начале лета, так и в конце вегетационного сезона.

С помощью компьютерной программы «Простая формула» выявлена зависимость накопления фторидов: 
2001 год (июль)

$y=+326,02 / \exp (x)+267,65$

2001 год (октябрь)

$y=1942,5 / \exp (x)+125,14$

2002 год (июнь)

$y=+1463,0 / x$

2002 год (октябрь)

$y=\sqrt{49922 / x}$

\section{ВЫВОДЫ}

В результате исследования лесных экосистем в пределах санитарно-защитной зоны Братского алюминиевого завода можно сделать следующие выводы: - древесная растительность представляет редины с полнотой $0,1-0,3$. Средний возраст деревьев в санитарно-защитной зоне не превышает 30 лет. В основном это деревья, сохранившиеся после сплошных санитарных рубок погибшего в результате высокого уровня загрязнения древостоя. Санитарные рубки проводились в 80-е годы;

- породный состав древесной растительности представлен сосной, лиственницей, единично елью;

- подрост в радиусе 1 - 2 км практически отсутствует, на более дальнем расстоянии - сильно угнетен, имеет очень малый линейный прирост (до нескольких сантиметров в год), практически на 100\% поврежден ожогами, продолжительность жизни хвои резко сокращена. Подрост лиственных пород Б, Ос. имеет большую высоту, но отличается многовершинностью и значительным поражением листьев (ожоги);

- подлесок представлен лиственными породами (различные виды ив, рябина, ольховник). 90\% подлеска имеют ожоги листьев;

- средний балл категории состояния деревьев составляет около 3 , что по шкале соответствует сильно ослабленным деревьям. Оценка состояния деревьев свидетельствует о сильном влиянии загрязнения на их жизнеспособность;

- исследования микробиологической активности почв, проведенные в санитарно-защитной зоне и за ее пределами, позволяют сделать вывод, что азотфиксация почвы резко снижена в радиусе до 8 км от БрАЗа, затем начинает возрастать. Интенсивность дыхания почвы также снижена в радиусе 8 км и постепенно возрастает к радиусу 20 км. Однако полного подавления активности почвы не произошло, что дает возможность прогнозировать развитие наиболее газоустойчивых растений в санитарно-защитной зоне завода;

- динамика накопления фторидов в листьях свидетельствует о том, что в самом начале вегетационного периода содержание фтора минимально, к концу вегетационного периода (сентябрь, октябрь) содержание фтора возрастает в $1,7-3$ раза в зависимости от удаления от источника загрязнения. Концентрация общего фтора такого уровня приводит к ожогам листвы и хвои, угнетению процесса фотосинтеза и отмиранию листьев и хвои;

- при выборе пород для лесовосстановления следует учитывать, что для санитарных зон необходимы самые газоустойчивые породы. В условиях с сильным уровнем загрязнения следует заменить породы на устойчивые к воздействию дымов и газов. По стойкости к воздействию атмосферных загрязнителей почти все лиственные породы превосходят хвойные породы, однако мягколиственные (береза, осина) не имеют такой ценной древесины, как хвойные. Рекомендуется оставлять как газоустойчивые следующие виды растений: багульник болотный (Ledum palustre), жимолость синяя (Lonicera xylosteum), малина (Rubus idaeus), рододендрон даурский (Rhododendron darski), смородина красная (Ribes rubrum), спирея (Spirea), черемуха (Padus racemosa). Эти виды растения слабо поражаются вредными выбросами. И, наконец, наиболее газоустойчивыми и, соответственно, рекомендуемыми к лесовосстановлению являются следующие виды: береза повислая (Betula pendula), боярышник (Crataegus saguinea), бузина красная (Sambucus racemosa), ива (Salix caprea), кизильник (Cotoneaster lucidus), ольха кустарниковая (Alnus fruticosa), роза иглистая (Rosa acicularis), рябина (Sorbus aucuparia), осина (Populus tremula).

\section{СПИСОК ЛИТЕРАТУРЫ}

1. ОСТ 56-69-83. Пробные площади лесоустроительные. Метод закладки.

2. Анучин Н. П. Лесная таксация. М.: Лесная промышленность, 1977.

3. Аринушкина Е. В. Руководство по химическому анализу почв. М., 1970.

4. Методика организации и проведения работ по мониторингу лесов СССР в рамках Международной Совместной Программы по оценке и мониторингу воздействий загрязнения воздуха на леса в регионе Европейской Экономической Комиссии ООН. Пушкин, 1987. 